\title{
DIE EKONOMIESE FAKULTEIT VAN DIE VRIJE UNIVERSITEIT.
}

Dit is vir my as oud-student van die beroemde Vrije Universiteit 'n besonder aangename voorreg om by die herdenking van die vyf-en-sewentigjarige bestaan van dié Universiteit, 'n paar besonderhede aangaande die Ekonomiese Fakulteit van die Vrije Universiteit aan die lesers van "Koers" te kan meedeel. Mag die enkele mededelinge daartoe bydra dat baie meer Suid-Afrikaanse studente aan die Vrije Universiteit sal gaan studeer.

Deur die „Vereeniging voor Hooger Onderwijs op Gereformeerden Grondslag" is 'n universiteit deur 'n Koninklike besluit van 12 Februarie 1879 opgerig onder die naam „Vrije Universiteit”.

Die gereformeerde karakter van die Vrije Universiteit word duidelik omskryf in Artikel 2 van die Reglement van die universiteit, wat as volg lui: „In diepe afhankelijkheid van de mogendheid des Heeren optredende, zal deze Universiteit, op den grondslag der gereformeerde beginselen, draagster trachten te zijn van het dubbele beginsel, „dat de vreeze des Heeren het beginsel der wijsheid is, en dat vrijmaking van uitwendige banden, om eeniglijk te steunen op de genade Gods, het meest bevorderlijk is ook aan den bloei der wetenschap.

Het „nil contra Deum aut bonos mores" indachtig, zullen Directeuren, Curatoren, hoogleeraren en studenten dienovereenkomstig steeds, binnen de perken door deze beide beginsel aangegeven, de Universiteit hebben diensbaar te maken aan de bevordering van Gods eer en van godzaligheid in den lande".

Wat 'n voorreg vir enige persoon wat nog aan die gereformeerde beginsels ' $n$ ereplek toeken om aan so 'n Gereformeerde universiteit as die Vrije te studeer.

Alhoewel die Vrije Universiteit nou reeds 75 jaar bestaan, dateer die Ekonomiese Fakulteit slegs sedert Oktober 1948. Die aantal ingeskrewe studente aan die Ekonomiese Fakulteit het egter snel aangewas, soos uit onderstaande tabel duidelik blyk:

$\begin{array}{ccccccc}1948 / 49 & 1949 / 50 & 1950 / 51 & 1951 / 52 & 1952 / 53 & 1953 / 54 & 1954 / 55 \\ 93 & 163 & 209 & 259 & 292 & 356 & 461\end{array}$

Ook die aantal leerkragte het in die sewe jaar vinnig toegeneem, t.w. van 11 in 1948 tot 18 in 1955.

Aangesien die meeste Suid-Afrikaanse studente na oorsese universiteite gaan vir gevorderde studie, sal ek slegs enkele besonderhede aan- 
gaande die doktorale studie aan die Ekonomiese Fakulteit van die Vrije Universiteit meedeel.

Die doktorale studie lei studente op tot selfstandige beoefening van die wetenskap en vind sy bekroning in die promosie tot doktor in die ekonomiese wetenskappe. Interessant is dit om daarop te let dat by die doktorae studie gewaak word teen $\boldsymbol{n}$ te enge spesialisasie deurdat twee hoofvakke en twee keusevakke geneem moet word. Verder word naas of in die plek van voordragkolleges, werkkolleges gegee. Elke student vir die doktorale studie is dan ook verplig om ten minste twee werkkolleges, één in die verpligte vak en éen in die keusevak, gedurende ten minste éen jaar by te woon en workstukke te maak. So 'n werkstuk is 'n bondige nota van beperkte omvang. Die student is verder verplig om 'n skripsie te maak in éen van die vakke wat hy verkies. So 'n skripsie moet in twee-voud by die betrokke hoogleraar ingelewer word. Bowendien is elke student verplig om vir ses weke praktiese werk te verrig in die Ekonomiese en Sosiale Instituut wat aan die Ekonomiese Fagulteit verbonde is.

In die eerste doktorale studiejaar moet ook nog die volgende propedeutiese tentamens afgelê word, t.w. in:

1. Wiskunde.

2. Sedeleer van die ekonomiese lewe.

3. Geskiedenis van die Moderne Wysbegeerte.

4. Sosiologie en Sosiografie.

Interessant is ook die feit dat Sosiologie 'n inherente deel van dic Ekonomiese opleiding kan uitmaak. Daar bestaan in die doktorale studie dan ook twee hoofstudierigtinge, nl.:

I. Die Ekonomies-Bedryfsekonomiese rigting:

II. Die Ekonomies-Sosiologiese rigting.

Die Ekonomies-Bedryfsekonomiese rigting omvat:

1. Ekonomie, insluitende die Geskiedenis van die Ekonomie en Ekonomiese Politiek.

2. Bedryfsekonomie.

3. 'n Keusevak.

4. 'n Keusevak.

Die Ekonomies-Sosiologiese rigting omvat:

1. Ekonomie, insluitende die Geskiedenis van die Ekonomie en Ekonomiese Politiek. 
2. Algemene en Beskrywende Sosiologie.

3. 'n Keusevak.

4. 'n Keusevak.

In bogenoemde rigtings kan die nadruk val op óf die Ekonomie óf die Bedryfsekonomie óf die Sosiologie. Die keuse van die werkkolleges moet by die hoofrigting aansluit. Studente wat die nadruk op Bedryfsekonomie laat val kry verligting in die Ekonomie maar moet by die Bedryfs-ekonomie verdere aandag gee aan Administratiewe Ofganisasie en Budgettering en Voortgesette Boekhouding.

Studente wat die nadruk laat val op die Sosiologie kry ook verligting in die Ekonomie maar moet by die Sosiologie aandag gee aan Sosiografie en Ekonomiese en Bedryfssosiologie.

Die keusevakke waarna hierbo verwys is, en waaruit die kandidaat twee moet kies, sluit in:

a. Algemene en Beskrywende Sosiologie.

b. Sosiografie.

c. Ekonomiese en Sosiale geskiedenis.

d. Ekonomiese Aardrykskunde.

e. Burgerlike en Handelsreg.

f. Staats- en Administratiewe Reg.

g. Arbeidsreg.

h. Leer van die Openbare Finansies.

i. Belastingsreg.

j. Statistiese analise.

k. Bedryfssielkunde.

1. Enige ander goedgekeurde vak.

Die doktorale studie neem normaalweg drie jaar, maar vir SuidAfrikaanse studente wat reeds in besit is van die graad M.Comm. of M.A. kan sekere vrystellings en vergunnings deur die Fakulteit van Ekonomiese Wetenskappe gemaak word. Elke geval sal egter op sy eie meriete behandel word.

Ten slotte nog ons beste wense aan die lede van die Fakulteit van Ekonomiese Wetenskappe van die Vrije Universiteit. Mag die Fakulteit steeds van krag tot krag gaan tot eer en verheerliking van die naam van God.

\section{B. VAN DEVENTER}

(Oud-student V.U.) 